可視化情報 Vol. 11 Suppl. No.1（1991年 7 月）

\title{
16 MOCVD度底管内での流九の可想化法の研究
}

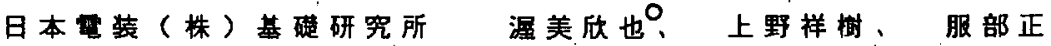

Study of New Flow Visualization Technique Using TiOz Particles

in MOCVD Reactor

kinya Atsumi*, Yoshiki Uena*, Tadashi Hattori*

The MOCVD technique is one of the most excellent process for the srowth of III - V semiconductor epilayers. In'this process, epilayer quality(i.e. thicknes.s uniformity)is determined largely by gas-flow dynamics in the reactor. An understanding of $g$ as flow patterns in the reactor is necessary. to obtain the good uniformity of epilayer on a large scale.

In this study, we developed a new method of generating micron sized $\mathrm{TiO}_{2}$ particles by the 2-step reaction of $\mathrm{TiCl}_{4}$. Using this technique, $\mathrm{T}_{\mathrm{i}} \mathrm{O}_{2}$ particles are generated very smooth and thick. We visualized by the scattering of a laser light sheet in a vertical reactor. With top inlet, and could observe stable gas-flow patterns for more than 30 minutes.

The experimental. results indicate that the fine gas-flow patterns on the 2-inch diameter substrate affects the thickness uniformity strongly.

1 ・はじめに

MOCVD (Metal Organic_Chemical Vapor_Deposition)は 化合物半導体エピタキシ ヤル成長法の1つであり、各供粭原料がスを基板上で热分解して単結晶成長させる方法 である。本方法は量産性に傮れることから特に注目されている。しかしながら反応管 内の加入の流れが成長膜の品を大をく左右することから反応管内のがスの流れを把握 することが極めて重要となる。実際には結晶成長における原料の輸送過程等はほとんど 解明されていないが、最近では流れの可視化(い(2)(3)や数值計算(4)(5)によって䆄極的 に反応管内の流れを解析しようとする動きがある。徉来より前者においては「门し14を加水 分解して $\mathrm{TiO}_{2}$ 䊉子を生成し反応管内に海入するトレーサ法が用いられてきたが、 $\mathrm{TiO}_{2}$ とH ${ }_{2} 0$ の反応性が激しいため反管内王力を变動させたり、チタンの水酸化物が副生成物と して配管内に付着し目詰まりを起こしやすいため、Ti $0_{2}$ 生成量を少なくし希薄なスモ一 ク状態でしか可視化できないといった問題点があった。著者らはいかにしたらで

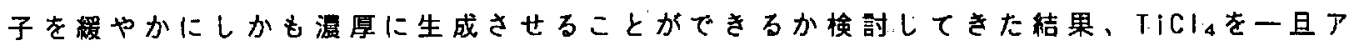
ルコキシドに变化させさらに方れを度管上部で加水分解し $\mathrm{TiO}_{2}$ 粒子に变える2段階 反応を用いると、上記問題点を解決でき鲜明な流れを摄影できることを見出だした。光の

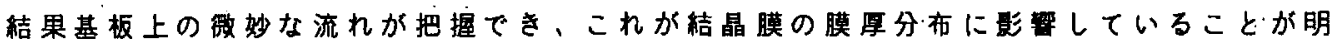
かとなった。

* nippondenso co., ltd: research lab. nissincho, a ICHI-gun, alchil, japan 


\section{2 , 実験装置}

テーパ付き円筒型反応管の例を图1に示す。原料ガス は筑をキャリアガスとして を1/4インチのがス酷を通して算入するが、原料かスの占 める割合は殿量なため放がスのみの流れとして考元ればよい。

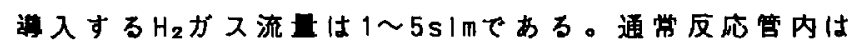
1〜0.1気死程度で行われている。クラファイト然のサでタ は离周波により加热され头の上にGaAs基板を設亚し、約 700

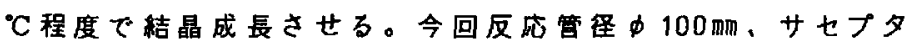
经の80mmのものを例にとり可視化した。この時の無次元項を 表 1 に示す。MOCVDではがス海入口を代表程にとるとレ イノルメ数は 50 程度と小さく、クヌーセン数、マッハ数とも

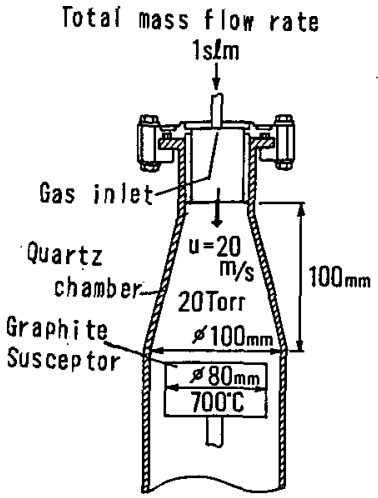

Fis. 1 Vertical Hocvo reactor 小さいことから非珐䋩性の粘性流体として扱ってょいことが わかる。また温度差によって生じる浮力と惯性力の比(グう

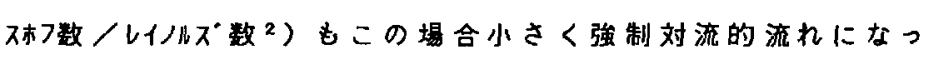
ていることがわかる。

今回反応管内の流れを可視化するにあたり、サ七

\begin{tabular}{|c|c|c|c|}
\hline \begin{tabular}{|c|c|c|} 
Di nensionless \\
numbe
\end{tabular} & $20 T a r 700^{\circ} \mathrm{C}$ & 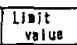 & Condition \\
\hline$R_{e}=\frac{\rho \cdot u d}{\mu}$ & 2051 & $<2000$ & $\begin{array}{l}\text { Laninar } \\
\text { flor }\end{array}$ \\
\hline$K_{n}=\frac{\lambda}{d}$ & $7 \times 10^{-4}$ & $<0.01$ & \begin{tabular}{|l} 
Yiscou \\
tion
\end{tabular} \\
\hline$M=\frac{u}{c}$ & $1.5 \times 10^{-2}$ & $\ll 1$ & \begin{tabular}{|l} 
Incanpre \\
ible
\end{tabular} \\
\hline 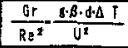 & $2 \times 10^{-4}$ & $\ll 1$ & $\begin{array}{l}\begin{array}{l}\text { Forced } \\
\text { convect ton }\end{array} \\
\text { con }\end{array}$ \\
\hline
\end{tabular}
プタ上の流れを詳細に検討するため実物の 2 倍のス ケールの矩形のアクリル製モテルチャンバを作し た。無次元項はレイノルズ数を一致させ大氞压下て

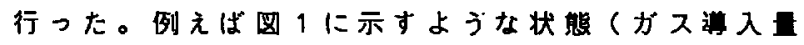
1slm，20Torr）を大気压で2倍スケールのモデル千 ヤンバにてレイノルス数を一致させると流速は䄪 5 $0 \mathrm{~mm} / \mathrm{sec}$ 程度の極めて遅い流れとなる。サセブタと ガスの温度差に関してはGr/R e 2を一定とし温 度差 $\Delta T$ を見䅡もると非常に小さい(0.01年以下)た めサセプタの温度は常盜とした。

今回製作した可視化実駼装を四 2 に示す。本装

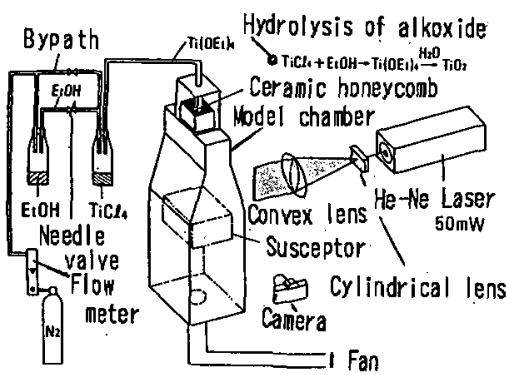

Fig. 2 Experimental apparatus for flow visualization 目の特徵は啝の生成方法にある。これはェタノ一

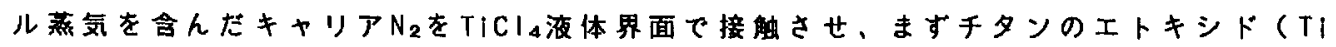
$\left(\mathrm{OCH}_{2} \mathrm{CH}_{3}\right)_{4}$ ：無色）を生成する。次にモテルチャンハ上に設目したセラミックハニカム (アルミナ製) 中を通す。セラミックハニカムは多孔性であるため水分を吸朔しており、

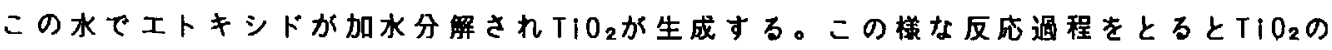

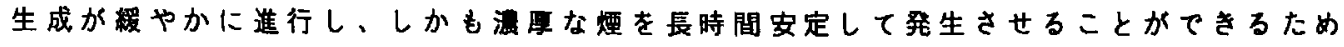
鲜明な流れを钼察することができる。可視化においては、He-Neレーザをシート状に出げ 流れの断面を覞察した。なおセラミックハニカムは整流格子の役目も果たしている。 


\section{3. 実験結果}

可視化写真の例を図 $3 に$ 示す。ガスが反応管内に導入されてサセプタに衝突し瀜がで きる瞬間（ａ）、サセブタ上の流れが剥離してきて盛り上がる状態（b）、かスが反応 管内に拡散していく状態（c）、加水分解が不足すると流束の内部まで反応ができすに $\mathrm{Ti} \mathrm{O}_{2}$ が生成できない状態（d）等を観察することができた。

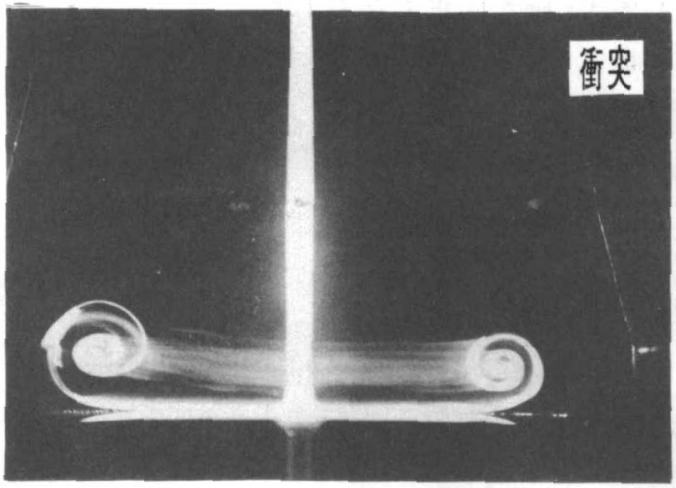

(a)

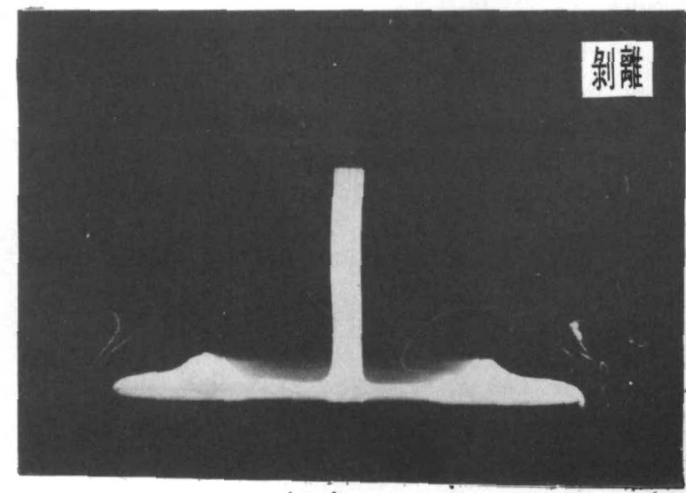

(b)

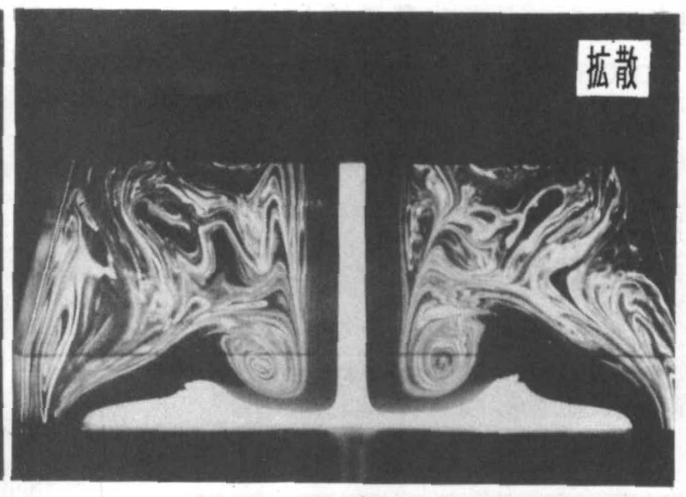

(c)

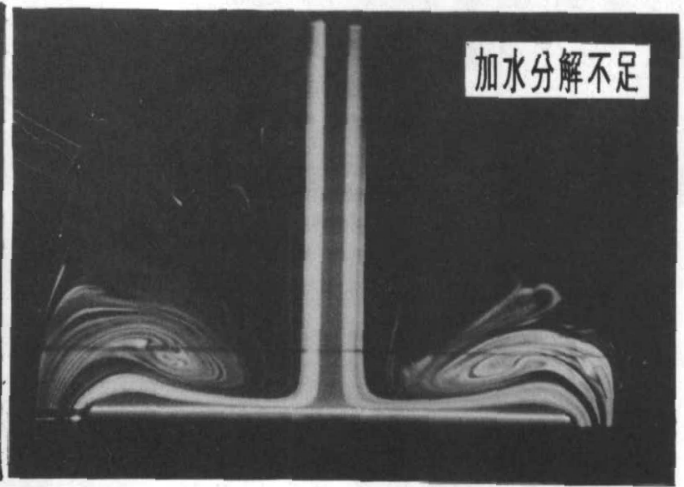

(d)

Fig. 3 Examples of flow visualization

(a) Collision with the susceptor(or the substrate)

(b) Separation on the susceptor (or the substrate)

(c) Diffusion in the reactor

(d) Lack of hydrolysis

図3（b）の流れについて考察すると、まず基板上に䕗入されたがはサセプタエッ ジ下部にて剥離が起こク、それがサセプタ上へ移動しカのハランスにより产の位置で保 たれているように観測される。この流れの剥離が起こる要因としては、サセプタエッジ の形状、反応管とサセプタの距離及びガス流量（流速）が考えられる。

実際にガス導入量 $1 \mathrm{~s} 1 \mathrm{~m}$ 压カ 20 Torrにて 2 インチ基板上にエピタキシャル成長した 膜の膜厚分布と耂の時の状態を示した可視化写真を比較すると、膜厚が厚くなっている 位且と基板上で流れが剥離して盛り上がっている位面とがー致している（図４，5）。 
そしてこの位置は道入ガス流量を増大していくと基板の外周方向へ移動して行く。図 6 は、が䢙入流量に対応したしイノルス数と剥離した盛り上がり部間の距離の関係を示 したものである。基板外徍以上に盛り上がク部を移鯂させるためには、3倍以上この

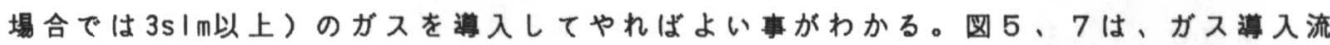
量 $3 \mathrm{~s} I \mathrm{~m}$, 圧力 1 O O Torrにてエピタキシャル成長したときの膜厚分布とその時の可視化 写真である。膜厚分布は、2 インチ基板上で $\pm 5 \%$ 初期の $\pm 35 \% に$ 比較して大变向上

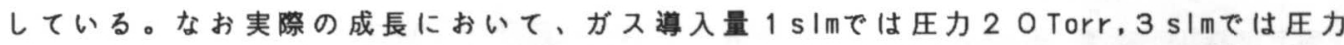
$100 \operatorname{Torr}$ としたは浮力と慣性力の比 $\mathrm{G} r / \mathrm{R} \mathrm{e}^{2}$ をほ同一の值にするためである (図 5)。

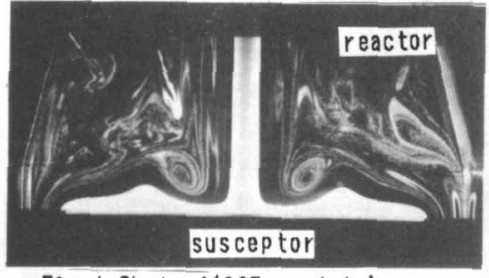

Fis.4 Photo 1(20Torr, $1 \mathrm{~s} / \mathrm{m})$

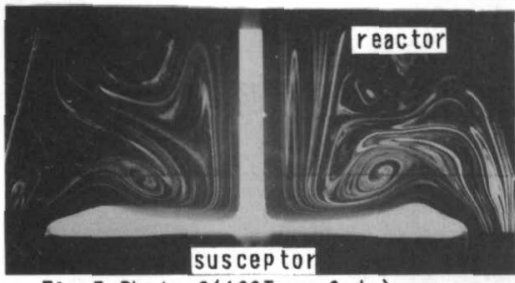

Fis. 7 Photo 2(100Torr, 3s Im)

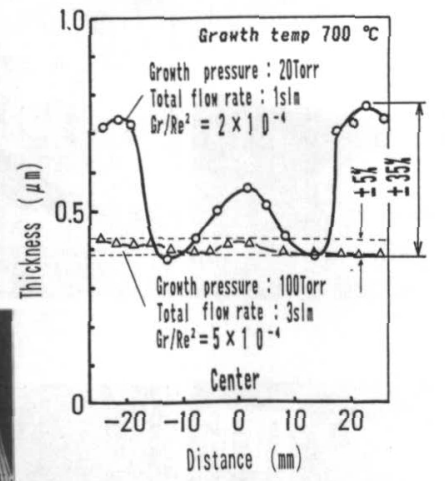

Fig. 5 Radial thickness uniformity

4.まとめ

(1) $\mathrm{TiO}_{2}$ 粒子を用いた注入トレーサ法にて、低流速領域の可視化を行った。

この様な領域での可視化で注意すべき点としては、1)スモークの圧力变動

2) 副生成物による配管の目詰まり等の外乱要因を排除しないと本当の流れを観

察できないということである。

(2) $\mathrm{TiCl}{ }_{4}$ の 2 段階反応により $\mathrm{TiO}_{2}$ 粒子を長時間安定して発生させることにより基板上の

微細な流れを把握することができた。

(3) 反応管へのガス導入量の差により、基板上で流れの剥離が起こっていることが明か となった。キャリアガス導入量を增大させ、これを基板の外周部へ移動させること

によりエピタキシャル成長膜の膜厚均一性を向上させることができた。

\section{参考文献}

(1) C.A.Wang et al. J.Crist.Growth $\underline{77(1986) 136}$

(2) D. I. Fotadis et al. J.Crist. Growth $\underline{85}$ (1987) 154

(3) M.De Keijser et al. J.Crist.Growth $\underline{92(1988) 33}$

(4) C.A.Wang et al. J.Crist. Growth $\underline{96(1989) 153}$

(5) A.H.Dilawari et al. J.Crist.Growth 97(1989)777 